\title{
Do Workers' Remittances Promote Financial Development in Sub-Sahara Africa Countries?
}

\author{
Taiwo V. Ojapinwa ${ }^{1} \&$ Oladipo T. Bashorun ${ }^{2}$ \\ ${ }^{1}$ Department of Economics, Lagos State University, Lagos, Nigeria \\ ${ }^{2}$ Department of Finance, University of Lagos, Akoka Yaba, Lagos, Nigeria \\ Correspondence: Taiwo V. Ojapinwa, Department of Economics, Lagos State University, Lagos, Nigeria. Tel: \\ 234-80-3417-2740. E-mail: ojapinwataiwo@gmail.com
}

Received: December 4, 2013

Accepted: January 2, 2014

Online Published: April 6, 2014

doi:10.5430/ijfr.v5n2p151

URL: http://dx.doi.org/10.5430/ijfr.v5n2p151

\begin{abstract}
This study examines the impact of workers' remittances on financial development in 32 Sub-Sahara Africa countries. In this paper we employ dynamic panel GMM model to study the potential effect of remittances on financial development with emphasis on financial intermediation. While the study depends on credit to private sector as a measure of financial development, past level of financial development, inflation, globalisation, FDI, size of government economic growth and worker remittances were controlled for. Employing data from 1996 -2010, the study discovers that workers' remittances affect financial development in a positive and significant way. This positive relationship suggests that remittances complements financial intermediation in SSA countries as exemplified by "endogenous growth" literature and the canonical intermediating model with the insights that remittances savings behaviour will generally influence equilibrium financial growth rates.
\end{abstract}

Keywords: remittances, financial development, dynamic panel data, SSA

\section{Introduction}

Workers' remittances by international migrants to their countries of origin have increased substantially during the last decades constituting the largest source of external finance for developing countries after foreign direct investment (FDI). While the figure sent to developing countries reached $\$ 325$ billion, the flows to Africa reached $\$ 40$ billion in 2010, equivalent to 2.6 percent of Africa's gross domestic product (GDP) (World Bank, 2011). Workers' remittances proved to be resilient during the global financial crisis, fell only by 5.4 percent in 2009 compared to a 36 percent decline in foreign direct investment (FDI) between 2008 and 2009 and a 73 percent decline in private debt and portfolio equity flows from their peak in 2007(World Bank, 2011a; 2011b). It is not surprising; therefore, that the role of remittances on economic growth has received great attention in the literature. One of the most influential studies on this area is Chami et al (2003). They study the impact of remittances on economic growth in 113 developing economies over the 1970-1998 and find a zero or negative relationship. Other studies that conducts cross-country growth regressions with specifications similar to those of Chami et al with similar conclusion are IMF (2005) and Barajas et al (2009).

In contrast however, Ratha (2005), Catrinescu et al (2009), Jongwanich (2007), Pradhan et al (2008), Adenutsi (2010) and Bali and Bali (2011) find some evidence of positive and significant relationship. Apart from Adenutsi that focus on 15 Sub-Sahara Africa countries other studies focus on developing and Pacific Island countries. However, the above study rely on the notion that the relationship between remittances and economic growth is direct despite Ramirez and Sharma (2008) assertion that, the extent to which remittances contribute to growth depends on the quality and the environment of the financial system of the recipient countries.

Mundaca (2005), Aggarwal, et al (2007), Guilioni and Araz (2006), Gupta et al (2007); Adenutsi (2011); Olubiyi (2009); Calderon, Fajnzylber and Lopez (2007) shift the frontier of the literature in this field towards providing answers to the question about what is the impact of remittances on financial development. Within neoclassical-financial intermediation theoretical framework for example Mundaca (2008) studies the effects that workers' remittances and financial intermediation have on economic growth in Latin America and certain countries in the Caribbean (LAC) over the 1970 - 2002 periods. Thus, in all the regressions, they control for population growth, 
education level, and also included a set of dummies for the years of study while adopting the First- Difference Generalized Method of Moments (GMM) of Arellano and Bond (1991) for panel data to take into account the possible endogeneity of the explanatory variables. After considering the effect of long-run investment and demographic variables, and controlling for fixed time and country effects, they generally conclude that making financial services more generally available should lead to even better use of remittances, thus boosting growth in these countries. Using the same GMM method of analysis, this conclusion is similar to that of Aggarwal et al (2006) who uses data on workers' remittance flows but this time on 99 developing countries during 1975-2003 to study the impact of remittances on financial sector development and particularly examine whether remittances contribute to increasing the aggregate level of deposits and credit intermediated by the local banking sector. The investigation of Nonam and Uddin (2011) on the interaction among foreign remittance, banking sector development and GDP in four South Asian nations with multivariate granger causality tests, based on error correction models and panel analysis from 1976 to 2005 further lend credence to the conclusion similar to that of Aggarwal et al (2006).

Extending the work of Aggarwal et al (2006) but with the same method of analysis, Peria, Mascaro and Moizeszowicz (2008) focus on Latin America and Caribbean region, but this time on 25 countries for the period $1975-2005$. The authors reveal that the impact of remittances on financial development is though positive but very marginal. In the author opinion, recurrent crises in the study area have created a climate of distrust in the banking system, which explains why remittances recipients are prone to use the financial system than in other region. This conclusion is in line with the work of Olubiyi (2009) and the recent work of Ojapinwa (2012) whose studies were based on Nigeria. While Olubiyi examines a direct relationship between remittances and financial sector performance, Ojapinwa tests financial development impact of remittances on economic growth. Adopting structural dynamic model, Olubiyi find that worker remittances show a sign of positive effect on demand deposit, positive and significant effect on liquidity and positive and significant effect on DMB credit and loan and Ojapinwa find the same but with remittances having indirect relationship with credit to private sector and money supply in Nigeria. However, the work of Olubiyi (2009), Ojapinwa (2012) and Adenutsi (2011) are country specific, it could not capture the complexity of human behaviour, countries dynamics and cannot be relevant in the need to harmonize regional policies (Baltagi and Levin, 1992; Hsiao, 2003; Baltagi, 2008). In addition, the reliance of the above studies on the traditional instrumental variable and at best the first difference GMM method to confront the problem of endogenity and unobserved country-specific effect to examine the remittance finance growth nexus is defective(Gujarati and Porter, 2008). The first difference although removes the time invariant individual effects and transform equation in a way that instrumental variable can be used, the possibility of high standard errors with arbitrariness in the choice of instruments would rather exercabate the potential problem of reverse causality and simultaneity bias. This is also based on the (Blundell and Bond, 1998) argument that an additional mild stationarity restriction on the initial conditions process allows the use of an extended system GMM estimator that uses lagged differences of $y t-1$ as instruments for equations in levels, in addition to lagged levels of yi $t$ as instruments for equations in first differences (see Arellano and Bover, 1995).

Dustmann and Kirchamp (2001) find that the savings of returning migrants may be an important source of start up capital for microenterprises. Similarly, in a study of thirty communities in West-Central Mexico, Massey and Parrado (1998) conclude that earnings from work in the United States provide an important source of start up capital in $21 \%$ of the new business formations. Woodruff and Zenteno (2001) also find that remittances are responsible for almost $20 \%$ of the capital invested in microenterprises throughout urban Mexico.

Giuliano and Ruiz-Arranz (2006) used internal instruments (lagged explanatory variables and system GMM techniques (in addition to OLS and fixed-effects panel regressions) to mitigate the endogeneity problem. Their sample included 73 countries with data over the 1975-2002 periods, measured in 5-year averages. Giuliano and Ruiz-Arranz regressed per capita GDP growth on the total remittances-to-GDP ratio, conditioning on the initial level of GDP per capita, the investment rate, population growth, the fiscal balance as a percentage of GDP tear of education, a of openness and inflation. They did not find a statistically significant effect on remittances and growth with this specification. However they explore possible interaction between the remittances to GDP ratio and financial deepening, as a way of testing whether remittances might enhance growth by relaxing credit constraints. They found significant negative interaction terms and interpreted these results as supportive of a credit constraint hypothesis: remittances appear to have positive effects on growth only in countries with small financial sectors, where their arrival serves to relax credit constraints. Ramirez and Sharma (2008) obtained similar results using an annual panel of 23 Latin American countries between 1990 and 2005. This study attempt to correct the endogeneity problem using the fully modified OLS technique rather than instrumental variables, but Adenutsi (2011) argues that fully modified OLS may not perform well in small samples. 
Catrinescu et al (2006) also used internal instrument (lagged remittances) in a study that included cross-sectional as well as various static and dynamic panel regressions on a dataset of 114 countries during the periods of 1991 to 2003. In addition to using dynamic panel methods, this study extends previous work by incorporating institutional variables into the analysis. Their controls included initial GDP per capita, the ratios of gross capital formation and net private capital inflows to GDP, institutional variables such as the United Nations Human Development Index, six governance indicators as in Kaufmann, Kraay, and Mastruzzi (2003), and risk ratings from the International Country Risk Guide $(I C R G)$. Though they found some evidence of a positive relationship between growth and the (log of the) remittance ratio, they concluded that this relationship was not very robust and was relatively mild.

Beine et al (2009) investigate the link between remittance receipts and financial openness with a sample of 66 mostly developing countries from 1980-2005. Using a dynamic generalized ordered logit model to deal with the categorical nature of the financial openness policy and a two-step method akin to two stage least squares to deal with the potential endogeneity of remittances, they account for the persistence of financial openness, initial conditions, trade openness, institutional quality and domestic financial development. Beine et al find a strong positive effect of remittances on financial openness, i.e. the more remittances a country receives; the more likely it will be financially open. Their report implies that the positive effect is both statistically significant and economically large. Chimhowu et al. (2004) find that in low-income countries, increased remittance inflows have led to distortions in the functioning of formal capital markets and also destabilizing exchange rate systems through the creation of parallel currency markets.

Generally however, the empirical literature on the effects of remittance flows, financial development and economic growth appears ambiguous, covering the full gamut from positive effects, to negative effects, to no discernible effects, and to conditional effects. Possible reasons for this ambiguity could be methodological and differences in regional and countries cover. An important one is likely to be the underlying data used to construct the time series for remittance flows. As argued in Chami et al. (2008), the balance of payments categories of employee compensation (ec) and migrant transfers $(\mathrm{mt})$ are conceptually quite different from and behave differently than workers' remittances $(w r)$. In particular, employee compensation is mostly related to either seasonal labour or the employment in embassies abroad, while migrant transfers refer to the one-time movements in funds associated with changes in residence. Furthermore, within countries, correlations between $w r$ and $c e$ tend to be small, or even negative in many cases. Unlike the common practice of summing the three categories in the literature, this study therefore, use $w r$, the narrower and more precise definition, which makes the data use to be unique.

The diversity of results can also be traced to the adoption of OLS, static panel, external instruments. Even though some studies employed dynamic panel following the Arellano-Bond (1991) procedure, this study employed dynamic panel system GMM framework developed by Blundell and Bond (1998) to ensure a more robust, more efficient, and more consistent coefficient and to fully solve the endogeneity and reverse causality problems associated with remittances and financial development that is yet to be satisfactorily addressed in the remittance, financial development and growth literature. Moreover, unlike previous studies which usually lump all developing countries in most cases, this study is unique by filling the literature gaps while focusing on Sahara African countries.

\section{Methodology}

To examine the relationship between financial development and remittances we apply dynamic panel IV system GMM model which takes into cognizance the endogeneity problem in the model. The parametric remittance-finance model can be written as:

$$
F D_{i, t}=\alpha F D_{i, t-1}+\psi^{\prime} X_{i, t}+u_{i, t}
$$

where $\mathrm{FD}$ is a measure of financial development, $\mathrm{FD}_{\mathrm{i}, \mathrm{t}-1}$ is that lagged financial development.

$\mathrm{X}$ represents the set of explanatory variables (other than that controls for other factors associated with economic growth, $\mathrm{u}$ is the error term, and the subscripts $i$ and $t$ represent country and time period, respectively.

As mentioned in the introduction many theoretical models show that financial development is likely endogenous (e.g. Greenwood and Jovanovic, 1990) which implies that $E\left(\varepsilon_{i, t} / \operatorname{Re} m / F D\right)=0$. Estimating model (1) directly will generate biased estimators (Arellano and Bond, 1991). We can handle this problem by introducing a set of instruments for Rem/FD. Then we can express $(\operatorname{Rem})_{i, t}$ in terms of these instruments $G_{i, t}$ as 


$$
(\mathrm{R} \text { e } m / F D)_{i, t}=g\left(G_{i, t}\right)+u_{i, t}
$$

where, for simplicity, $g\left(G_{i, t}\right)$ is assumed to be parametric, say $g\left(G_{i, t}\right)=b^{\prime} G_{i, t}$. We choose lagged explanatory variables as instruments. Thus, (2) can be written as

$$
(\mathrm{Re} m / F D)_{i, t}=b^{\prime} Z_{i, t-1}+u_{i, t}
$$

where $Z$ represents all the explanatory variables in (3)

We assume that $E\left(\varepsilon_{i, t} / Z_{i, t-1,} u_{i, t}\right)=E\left(\varepsilon_{i, t} / u_{i, t}\right)$. It then follows that $E\left(\varepsilon_{i, t} / u_{i, t}\right) \neq 0$, since $E\left(\varepsilon_{i, t} / \operatorname{Re} m / F D\right) \neq 0$. Hence, one can decompose $\varepsilon_{i, t}$ into $\xi_{i}\left(u_{i, t}\right)+\varepsilon_{i, t}$, where $\xi_{i}\left(u_{i, t}\right)=E\left(\varepsilon_{i, t} / u_{i, t}\right)$ and $\varepsilon_{i, t}=\varepsilon_{i, t}-E\left(\varepsilon_{i, t} / u_{i, t}\right)$. Equation (2) then becomes

$$
F D_{i, t}=\alpha F D_{i, t-1}+\psi^{\prime} X+\xi\left(u_{i, t}\right)+\varepsilon_{i, t}
$$

We replace the unobservable $u_{i, t}$ by the observable $\widehat{u}_{i, t}=(\operatorname{Re} m / F D)_{i, t}-\hat{\psi}^{\prime} Z_{i, t-1}$. Then equation (4) becomes

$$
F D_{i, t}=\alpha F D_{i, t-1}+\psi^{\prime} X+\xi\left(\widehat{u}_{i, t}\right)+\varepsilon_{i \bullet, t}
$$

Where the error $\varepsilon_{i^{*}, t}=\varepsilon_{i, t}+\xi_{i}\left(u_{i, t}\right)-\xi_{i}\left(\widehat{u}_{i, t}\right)$.

One can use Arellano and Bond (1991) two-step white period, Arellano and Bover (1995) weighting matrix estimators to obtain consistent estimation of $\alpha$ and $\psi$ in the, say $\hat{\alpha}$ and $\hat{\psi}$. It is of course $\hat{f}(\operatorname{Re} m / F D)_{i, t}$ the estimated function that we are interested in, since it captures the marginal effects of the remittance/financial intermediary variable clean of any endogeneity.

The data set we use is from World Development Indicators (WDI). It consists of observations for 32 countries for the period 1996-2010. Table 1 represents the list of countries that are included in our sample and Table 2 provides summary statistics on the variables used in this paper and their correlations with each other.

Table 1. Country list, 32 SSA country-samples

Angola; Botswana; Cameroon; Cape Verde; Congo Rep; Cote de'Ivore; Djibouti; Equatorial Guinea; Gabon; Mauritius; Namibia; Nigeria; Senegal; Seychelles; Sudan; South Africa, Swaziland; Benin; Burkina Faso; Burundi; Central African Republic; Chad; Congo Dem. Rep; Eritrea; Ethiopia; Ghana; Gambia; Guinea; Kenya; Lesotho; Liberia; Madagascar; Malawi; Mali; Mozambique; Niger; Sierra Leone, Mauritania; Togo; Uganda; Zambia and Zimbabwe.

Meanwhile, there has been an extension search for good instruments to measure financial development in the empirical literature since different indicators captures different aspects of the financial system. Earlier studies based there financial development measurement only on monetary aggregates such as M1 or M2, which are more related to the ability of the financial system to provide transaction services (Demetriadies and Andrianva, 2004; Orozco and Fedewa, 2005). For instance,Aggarwa et al (2006) argue that the growth of private financial assets using the size of broad money (M2 or M3) indicates the liquidity position of the financial system and measures the degree of monetization and overall size of financial market development. Indeed, economies with underdeveloped financial systems may have a high ratio of M2 to GDP, as money is used as a store of value in the absence of other more attractive alternative (Adenutsi, 2010). While Olayiwola, Osabuohien and Rapuluchukwu (2012) called M2/GDP a measure of the rate of financial system maturity, it is better known in the literature as a measure of financial deepening.

The credit to private sector measures is also widely used in the literature and measures the ability of financial sector to pooling savings and finance private and illiquid investments (Levine et al, 2000; World Bank, 2005; Aggarwal et al, 2006). This measure excludes those credits granted to government official, public expenditures as well as those credits issued by the central bank and is the ability to canalize idiosyncratic funds from large savers to investors. The 
assumption is that financial systems that allocate more credit to private firms are more engaged in research and development, providing risk management services, mobilizing savings and facilitating transactions. More so it assumes that commercial banks are better at evaluating the potential returns and risks of various projects. The measure is then better known in the literature as a measure of financial intermediation. Bank capital to assets is also commonly employed in the literature. This is the ratio of bank capital and reserves to total assets. Capital and reserves include funds contributed by owners, retained earnings, general and special reserves, provisions, and valuation adjustments. Quasi-liquid liabilities as \% GDP are defined as currency plus demand and interest-bearing liabilities of banks and non-bank financial intermediaries as percent of GDP. The quasi money reflected largely, the growth in time deposits, especially percentage growth in the foreign currency deposits component with deposit money banks, as well as the public preference for the term deposits to equities, following the crash of the stock market.

To capture the capital market aspect of financial development Nwokoma (2002) and Ayadi et al (2013) employ market capitalization. Ayadi et al on Financial Development, Bank Efficiency and Economic Growth across the Mediterranean for instance employ five measures of financial development which includes: the amount of bank credit to the private sector (as \% of GDP), the share of bank deposits (as \% of GDP), Meta-efficiency as the distance of a bank from the meta-frontier, which is defined by the product of country cost efficiency and technical rate of growth (TRG). To capture the stock market aspect, Ayadi et al include stock market capitalisation (as \% of GDP) to provide an estimate of the size of the equity market. While stock market total value traded (as \% of GDP) was used as a measure of the extent of activities in the domestic equity markets, stock market turnover (Value traded over market capitalisation) is included to measure the liquidity of the stock market.

Following Levine, Loayza and Beck (2000) this study therefore uses two measures: credit to private sector - GDP ratio (CPS/GDP) and broad money supply -GDP ratio (M2/GDP) to capture the role of financial development. The reasons are based on Argenor and Montiel (2008) argument that (1) equity markets continue to be small or nonexistent in many SSA countries (2) that financial markets in the vast majority these economies continue to be dominated by a single type of institution - the commercial bank, thus, the menu of assets available to private savers is limited to commercial bank. Another reason is because this study is mainly interested in capturing the role provided by banks through the mechanism of money supply and financial intermediation which views banks primarily as maturity transformers.

Meanwhile, given the magnitude of remittances in the aggregate and the likelihood that their uniqueness implies different macroeconomic effects, researchers must take care to define remittances properly from a measurement point of view and to compile the appropriate data when conducting analysis. The literature has highlighted three components of the balance of payments in regard to compiling statistics on remittances. The first component, workers' remittances, records current transfers by migrants who are employed in, and considered a resident of, the countries that host them. A migrant in this case is a person who stays or is expected to stay in his or her host country for a year or more. Workers' remittances normally involve persons related to one another and are recorded under current transfers, according to the fifth edition of the Balance of Payments Manual (BPM). The second component, employee compensation, is composed of wages, salaries, and other benefits earned by individuals in countries other than those in which they are residents for work performed for and paid for by residents of those countries. According to $B P M$, compensation of employees is included under income in the current account. Finally, migrants' transfers are contra-entries to the flow of goods and changes in financial items that arise from individuals' change of residence from one country to another. In BPM, migrants' transfers are recorded in the capital account of the balance of payments under capital transfers of nongovernment sectors. Of these three categories, workers' remittance and compensation of employees better closely conforms to the notion that researchers and policymakers have in mind when discussing remittance flows. A common practice in the literature, however, has been to sum the three categories when compiling statistics on remittances. Recent examples can be found in Ratha (2003), World Bank (2005), (IMF, 2005), and including those by Aggarwal et al (2006), Kiiru (2010) and Kure and Nwosu, (2010) among others. Others like OECD (2006) and Ahortor and Adeuntsi (2011) have also gone ahead to add other current transfers plus other additional category in the Balance of Payments Statistics (BOPS). Inclusion of migrants' transfers may sufficiently pollute the database with non-remittance behavioural characteristics, consequently renders any specification and conclusions more egregious. This study therefore employs workers' remittances category based on the argument that it better closely conforms to the notion that researchers and policymakers have in mind when discussing remittance flows. It is however recognised in this study that workers' remittance data are underestimated due to the use of informal channels. 


\section{Empirical Results}

We report the empirical results using panel 2 stage least square, Arellano and Bond and Blundell and Bond GMM in Table 1 below. We conduct and report two tests to show the validity of our instruments. First, we present the $\mathrm{F}$ statistic for weak instruments as suggested by Stock and Yogo (2002). This is a test of the significance of our instruments in predicting remittances. In every regression the F-statistics is above the critical value, at 5 percent significance, indicating that our estimates do not suffer from a weak instruments problem. Second, we report the Sargan and Hansen test of over-identifying restrictions. The joint null hypothesis in this case is that the instruments are uncorrelated with the error term and that excluded instruments are correctly excluded from the estimated equation. Again, these tests confirm the validity of our instruments.

In all regressions we control for both log of credit to private individual as a measure of financial development; level of GDP per capita, inflation rate, population growth rate, for the extent of trade openness, foreign direct investment, gross capital expenditure and remittances itself. Across all estimations, we find that past realisation of both measures of financial development impact positively and significantly on its contemporaneous levels. While the financial development dynamics are so significant that a percentage increase in past realisations of credit to private sector explains about 0.57 in its current values within the sampled SSA countries.

As expected, the results on Table 2 confirm that financial development is positively affected by the inflow of FDI, level of income across all measure, government expenditure, and level of domestic investment. Meanwhile the extent of trade openness appears to have a negative effect. This FDI result might not be unconnected with Grossman and Helpman (1991) proposition that it may facilitate the transfer or diffusion of managerial and technological know-how - particularly in the form of new varieties of capital inputs, and improve the skills composition of the labour force as a result of "learning by doing" effects, investment in formal education, and on-the-job training.

As expected, the results on Table 3.1 also confirm that financial development is positively affected by an increase in domestic investment. This is consistent with theory and literature (Demetriades and Andrianova, 2004, Diamond, 1986, Bencivenga and Smith, 1991, King and Levine, 1993, Beck, Levine, Loayza, 2000, Xu, 2000, Khan, 2001, Rioja and Valev, 2003). One percent increase in domestic investment increase GDP per capita by 3.37 percent. This is similar to the first different result which shows 3.61 percent increase that dissimilar to the two-stage which is only significant at 10 percent level. Surprisingly, inflation variable is positively signed and significant in the GMM estimators. One possible explanation for the result might be as a result of the central bankers and policy makers' argument that positive but gentle inflation is required for future profitability of investment.

Surprisingly, globalization (openness) index has a negative instead of a positive sign. Statistically, the openness are significant which indicate that a percentage increase in openness would reduce financial development by 5.19 percent in term of first differenced and 4.91 percent for system GMM. This however implies that SSA has not really benefited from globalization.

Table 2. Estimated empirical results

\begin{tabular}{llcl}
\hline \multicolumn{2}{l}{ Dependent Variable: FD } & & \\
\hline Regressors & Panel 2SLS & Arellano \&Bond & Blundell \&Bond \\
\hline FD(-1) & 1 & 2 & 3 \\
& $\mathbf{1 . 0 1 3 4}$ & $\mathbf{0 . 5 7 0 8}$ & $\mathbf{0 . 5 7 2 4}$ \\
& 0.0050 & 0.0309 & 0.0061 \\
FDI & 0.0000 & 0.0000 & 0.0000 \\
& 0.0066 & $\mathbf{0 . 0 9 2 9}$ & $\mathbf{0 . 0 8 9 9}$ \\
& 0.0229 & 0.1507 & 0.0152 \\
GCEG & 0.7729 & 0.0028 & 0.0000 \\
& -0.0297 & 0.2069 & $\mathbf{0 . 1 9 6 6}$ \\
& 0.0190 & 0.1508 & 0.0387 \\
INF & 0.1193 & 0.1709 & 0.0000 \\
& 0.0027 & $\mathbf{0 . 0 3 4 3}$ & $\mathbf{0 . 0 4 1 7}$ \\
& 0.0069 & 0.0081 & 0.0066 \\
Y & 0.6970 & 0.0000 & 0.0000 \\
& 0.0900 & $\mathbf{1 2 . 6 8 0 8}$ & $\mathbf{1 3 . 3 5 5 4}$ \\
& 0.0885 & 2.3323 & 1.0084 \\
& 0.3096 & 0.0000 & 0.0000 \\
\hline
\end{tabular}




\begin{tabular}{llll}
\hline OPEN & -0.4299 & $\mathbf{- 5 . 1 8 7 1}$ & -4.9117 \\
& 0.2935 & 0.7600 & 0.8910 \\
I & 0.1438 & 0.0000 & 0.0000 \\
& $\mathbf{0 . 6 5 6 8}$ & $\mathbf{3 . 6 1 9 5}$ & $\mathbf{3 . 6 7 2 0}$ \\
& 0.3837 & 0.5944 & 0.3572 \\
REM & 0.0878 & 0.0000 & 0.0000 \\
& -0.0007 & -0.2456 & -0.2495 \\
& 0.0243 & 0.1573 & 0.0970 \\
\hline Observation & 0.9774 & 0.1200 & 0.0105 \\
No of Countries & 383 & 353 & 353 \\
Instrument Rank & - & 32 & 32 \\
\hline
\end{tabular}

Note: This Result computed from E-View 7.0. The number in bold and italic are is significant at 1 percent level, the number in italic indicate significant at 5 percent level and in bold indicate significant at 10 percent level

Remittances have a positive relationship with credits to private sector. Assuming a causal relationship, a percentage point increase in the share of remittances to GDP suggests around a 0.25 percentage point increase in the ratio of credit to private sector to GDP. The results from the first differenced and panel two-stage are dissimilar to that of system GMM in terms of significance. This might be as a result of my first-stage statistics of the 2SLS regression that my instruments were weak. With weak instruments the 2SLS methods are likely to be biased in the way of OLS estimator. These results however support both the literature (Aggarwal et al, 2006; Olubiyi, 2009) and the theoretical implication of our model, that remittance may increase the depth and breadth of domestic financial markets and lead to an increase in the degree of efficiency of the financial intermediation process, by lowering costs and "excessive" profits associated with monopolistic or cartelized markets. In turn, improved efficiency may lead to lower mark-up rates in banking, a lower cost of investment, and higher growth rates (see Levine, 1996; Baldwin and Forslid, 2000) as argued in Argenor and Montiel (2008).

\section{Conclusion}

In this paper we employ dynamic panel GMM model to study the potential effect of remittances on financial development with emphasis on financial intermediation. While the study depends on credit to private sector as a measure of financial development, past level of financial development, inflation, globalisation, FDI, size of government economic growth and worker remittances were controlled for. Employing data from 32 SSA countries between $1996-2010$, the study discovers that workers' remittances affect financial development in a positive and significant way. This positive relationship suggests that remittances complements financial intermediation in SSA countries.

The result implies that, saving from remittances and their intermediation through the financial sector leads to a more efficient allocation of resources. That is if remittances flows are well mobilized, properly canalized to and efficiently used by the financial sector, one should expect a greater effect of remittances on economic growth. This supports the notion that remittances transferred through formal system paves the way for recipients to demand and gain access to other financial products and services. This further implies that remittances capital can boost the credit channel through various pass-through effects and ultimately affect monetary policy goals. The study concludes that the effects of remittances on financial development are more enhanced in deeper financial systems, supporting complementarities of remittances and financial development system. These results are pointer to the fact that remittances are important factors that influence economic growth in SSA, which although is precondition upon financial intermediaries playing the valuable role of acting as facilitators to (i) produce information ex-ante about possible investments (ii) allocate remittances capital accordingly (iii) monitor remittance investments and exert corporate governance after providing finance (iv) facilitate the trading, diversification, and management of risk (v) mobilize and pool savings and (vi) ease the exchange of goods and services. These as exemplified by "endogenous growth" literature and the canonical intermediating model with the insights that remittances savings behaviour will generally influence equilibrium financial growth rates.

\section{References}

Adenutsi, D.E. (2011). Do Remittances Alleviate Poverty and Income Inequality in Poor Countries? Empirical Evidence from Sub-Saharan Africa.

Agenor, P. R., \& Montiel, P.J. (2008). Development Macroeconomics ( $3^{\text {rd }}$ ed.). Princeton University Press. 
Aggarwal, R., Demirguc-Kunt, R., \& Montiel, P.J. (2006). Do Workers' Remittances Promote Financial Development? World Bank Policy Research Working Paper No. 3957 (Washington: World Bank). http://dx.doi.org/10.1596/1813-9450-3957

Ahortor, C.R.K., \& Adenutsi, D.E. (2009). The Impact of Remittances on Economic Growth in Small-Open Developing Countries. Journal of Applied Sciences, 9(18), 3275-3286. http://dx.doi.org/10.3923/jas.2009.3275.3286

Arellano, M., \& Bond, S.R. (1991, April). Some Tests of Specification for Panel Data: Monte Carlo Evidence and an Application to Employment Equations. Review of Economic Studies, 58(2), 277-297. http://dx.doi.org/10.2307/2297968

Arellano, M., \& Bover, O. (1995). Another Look at the Instrumental Variables Estimation of Error-Component Models. Journal of Econometrics, 68, 29-52. http://dx.doi.org/10.1016/0304-4076(94)01642-D

Ayadi, R., Arbak, E., Ben-Naceur, S., \& De Groen, W.P. (2013). Financial Development, Bank Efficiency and Economic Growth across the Mediterranean. MEDPRO Technical Report No. 30/March 2013.

Baldwin, R., \& Forslid, R. (2000, April). Trade Liberalization and Endogenous Growth. Journal of International Economics, 50, 497-517. http://dx.doi.org/10.1016/S0022-1996(99)00008-2

Baltagi, B.H. (2005). Econometric Analysis of Panel Data ( $3^{\text {rd }}$ ed.). John Wiley \& Sons Ltd, The Atrium, Southern Gate, Chichester, West Sussex, England, p.147.

Barajas, A., Chami, R., Fullenkamp, C., Gapen, M., \& Montiel, P. (2009). Do Workers' Remittances Promote Economic Growth? IMF Working Paper 153/2009.

Beine, M., Lodigiani, E., \& Vermeulen, R. (2009). Remittances and Financial Openness. CREA Discussion Paper Series from Centre for Research in Economic Analysis, University of Luxembourg.

Bencivenga, V. R., \& Smith, B.D. (1991, April). Financial Intermediation and Endogenous Growth. Review of Economic Studies, 58, 195-209. http://dx.doi.org/10.2307/2297964

Catrinescua, N., Leon-Ledesmab, M., Pirachac, M., \& Quillind. B. (2009). Remittances, Institutions, and Economic Growth. World Development, 37(1), 81-92. http://dx.doi.org/10.1016/j.worlddev.2008.02.004

Chimhowu, A., Piesse, J., \& Pinder, C. (2004). Assessing the Impact of Migrant Workers Remittances on Poverty. Presented at the EDIAS Conference on New Directions in Impact Assessment for Development: Methods and Practice, 24-25.

Demetriades, P., \& Andrianova, S. (2004). Finance and Growth: What We Know and What We Need to Know. In C. Goodhart, (Ed.), Financial Development and Economic Growth: Explaining the Links (pp. 38-65). Palgrave Macmillan: Basingstoke and New York.

Giuliano, P., \& Ruiz-Arranz, M. (2006). Remittances, Financial Development, and Growth. IZA Discussion Paper No. 216.

Grossman, G. M., \& Helpman, E. (1991). Innovation and Growth in the World Economy. Cambridge, Mass.: MIT Press.

Gupta, S., Pattillo, C., \& Wagh. S. (2007). Impact of Remittances on Poverty and Financial Development in Sub-Saharan Africa. Working Paper 07/38. International Monetary Fund, Washington, DC. http://dx.doi.org/10.5089/9781451866025.001

Holtz-Eakin, D., (1988). Testing for Individual Effects in Autoregressive Models. Journal of Econometrics. http://dx.doi.org/10.1016/0304-4076(88)90060-7

Hsiao, C. (2003). Analysis of Panel Data. Cambridge University Press, Cambridge. http://dx.doi.org/10.1017/CBO9780511754203

International Monetary Fund. (2005). Two Current Issues Facing Developing Countries. World Economic Outlook, April 2005 (Washington).

Jongwanich, J. (2007). Workers' Remittances, Economic Growth and Poverty in Developing Asia and the Pacific Countries. United Nations Economic and Social Commission for Asia and the Pacific Working Paper WP/07/01, UNESCAP, Bangkok, Thailand.

Khan, A. (2001). Financial Development and Economic Growth. Macroeconomics Dynamics, 5, 413-433. 
Kiiru, J. M. (2010). Remittances and Poverty in Kenya.University of Nairobi School of Economics Kenya.

Kure, E, \& Nwosu. C.P. (2008). Worker's Remittances and Economic Growth Evidences from Nigeria. Department of Research Central Bank of Nigeria Being a paper prepared for Young Statisticians Conference held at Saint George Hotel, between 1stand 3rdJuly 2008, Pretoria, South Africa.

Levine, R., Loayza, N., \& Beck, T. (2000a). Financial Intermediation and Growth: Causality and Causes. Journal of Monetary Economics, 31-77. http://dx.doi.org/10.1016/S0304-3932(00)00017-9

Massey, D., \& E. Parrado. (1998). International Migration and Business Formation in Mexico. Social Science Quarterly, 79(1), 1-20.

Mundaca, G. B. (2008). Can Remittances Enhance Economic Growth? The Role of Financial Markets Development. Mimeo. University of Oslo.

Nonam A.M., \& Uddin, G.S. (2011). Remittances and Banking Sector Development in South Asia. International Journal of Banking and Finance, 8(4), Article 3. Retrieved from http://epublications.bond.edu.au/ijbf/vol8/iss $4 / 3$

Nwokoma, N.I. (2002). Stock Market Performance and Macroeconomic Indicators Nexus in Nigeria: An Empirical Investigation. Nigerian Journal of Economic and Social Studies, 44-62.

Ojapinwa, T. V. (2012). Workers' Remittances and Economic Performance in Nigeria: An Econometrics Analysis. University of Jos Journal of Economics, 4(14), 295-301.

Ojapinwa, T.V., \& Odekunle, L.A. (2013). Workers' Remittance and Their Effect on the Level of Investment in Nigeria: An Empirical Analysis. International Journal of Economics and Finance, Canadian Center of Science and Education, 5(4).

Olayiwola, W., Osabuohien, E., \& Rapuluchukwu, R. (2012). Inflation and Financial Development in Nigeria. Financial Sector Issues and Economic Development in Nigeria, P. 56 Vol 2 of Essay in Hournour of Professor Adedoyin Soyinbo.

Orozco, M., \& Fedewa, R. (2005). Leveraging Efforts on Remittances and Financial Intermediation. Report Commissioned by the Inter-American Development Bank.

Ozurumba, B. A. (2013, February). Migrant's Remittances and Economic Growth in Sub Saharan Africa: Evidence From Nigeria, Ghana And South Africa. Interdisciplinary Journal of Contemporary Research In Business, Institute of Interdisciplinary Business Research 534, 4(10).

Ramirez, M. D., \& Sharma, H. (2008). Remittances and Growth in Latin America: A Panel Unit Root and Panel Co integration Analysis. Economics Department Working Paper No. 51, Yale University, New Haven.

Ratha, D. (2005). Enhancing the Development Effect of Remittance to Developing Countries. In Global Development Finance World Bank, Washington, D.C.

Rioja, F., \& Valev, N. (2003). Does One Size Fit All? A Re-examination of the Finance Growth Relationship. Journal of Development Economics.

Woodruff, C., \& Zenteno, R. (2001). Remittances and Microenterprises in Mexico. UCSD Graduate School of International Relations and Pacific Studies Working Paper. University of California. San Diego.

World Bank. (2010). World Development Indicators Online Database.

World Bank. (2011). Migration and Remittances Factbook. Online Version.

$\mathrm{Xu}, \mathrm{Z}$. (2000). Financial Development, Investment and Growth. Economic Inquiry, 38, 331-345. http://dx.doi.org/10.1111/j.1465-7295.2000.tb00021.x 